\title{
MALIGNANT PILOMATRICOMA IN A YOUNG DOG
}

\author{
Eun-Joo Lee ${ }^{1,2}$, Ah-Young Kim ${ }^{1,2}$, Eun-Mi Lee ${ }^{1,2}$, Jin-Kyu Park ${ }^{1}$, Kyu-Shik Jeong ${ }^{1,2 *}$ \\ ${ }^{1}$ College of Veterinary Medicine, Kyungpook National University, Daegu, Republic of Korea \\ ${ }^{2}$ Stem Cell Therapeutic Research Institute, Kyungpook National University, Daegu, Republic of Korea
}

(Received 29 March; Accepted 13 July 2016)

\begin{abstract}
Malignant pilomatricoma is malignant follicular tumor with only matrical differentiation. Malignant pilomatricoma is rare in dogs. There is little information about sex, breed and age predisposition. There are a few reports of canine malignant pilomatricoma in middle to old age dogs. However, this neoplasm was resected from 1-year-old intact male miniature poodle. The neoplasm was found in the dorsal part of the neck. The mass was firm and protruded. On gross findings the size of the mass was $3 \times 2 \times 1.5 \mathrm{~cm}$. The mass was located in the deep dermis and subcutaneous layer. The mass was composed of several lobules of grey-white chalky material. Microscopically, the mass was composed of several large and small lobules. There were basophilic round to oval basaloid cells at the periphery of the lobules. The basophilic cells showed abrupt keratinization. Numerous ghost cells were observed in the center of the mass. The ghost cells had abundant eosinophilic cytoplasm without a nucleus. The basophilic basaloid cells showed numerous atypical mitotic figures. Cellularity was high and pleomorphism was remarkable. No lymphatic metastasis was observed. We reported a rare case of malignant pilomatricoma in a 1-year-old young dog.
\end{abstract}

Key words: Malignant pilomatricoma; Mitotic atypia; Mitotic index; Young dog

\section{INTRODUCTION}

Pilomatricoma is a benign follicular tumor with matrical differentiation. It has no sex predilection. Most cases of pilomatricoma in dogs arise between 2 and 7 years of age. Kerry Blue Terrier, soft-coated Wheaton Terrier, standard poodles, Old English sheepdogs show breed predisposition to pilomatricoma. Its prominent features include the presence of basophilic cells on the periphery of the lobules, ghost cells with abundant eosinophilic cytoplasm without a nucleus, and abrupt keratinization [1].

Malignant pilomatricoma (MP) is the malignant counterpart of pilomatricoma. Its microscopic features are similar to that of pilomatricoma, except for the high mitotic index, atypical mitoses, and lymphatic metastasis of neoplastic cells, which are remarkable in the malignant form of the disease. The metastases of MP spread via the lymphatics to the bone, liver, lung, and spleen [2]. The incidence of MP in dogs

*Corresponding author: e-mail: jeongks@knu.ac.kr 
is extremely low. There are only 12 reported cases of canine MP. Though there is little information about age, breed and sex predilection of MP, all 12 cases were from middle to old age dogs. Here, we report a case of MP in a 1-year-old dog.

\section{CASE PRESENTATION}

A neoplasm from 1-year-old intact male miniature poodle was submitted to the Kyungpook National University College of Veterinary Medicine. The dog did not show any clinical symptoms of the neoplasm, such as lameness or neurological signs. The neoplasm was found in the dorsal part of the neck. The mass had rapidly increased in size. The resected specimen $(3 \times 2 \times 1.5 \mathrm{~cm})$ was firm, well circumscribed, and located in the deep dermis and subcutaneous layer. Several lobules of grey-white chalky material were observed on the cut-surface of the tumor (Figure 1).
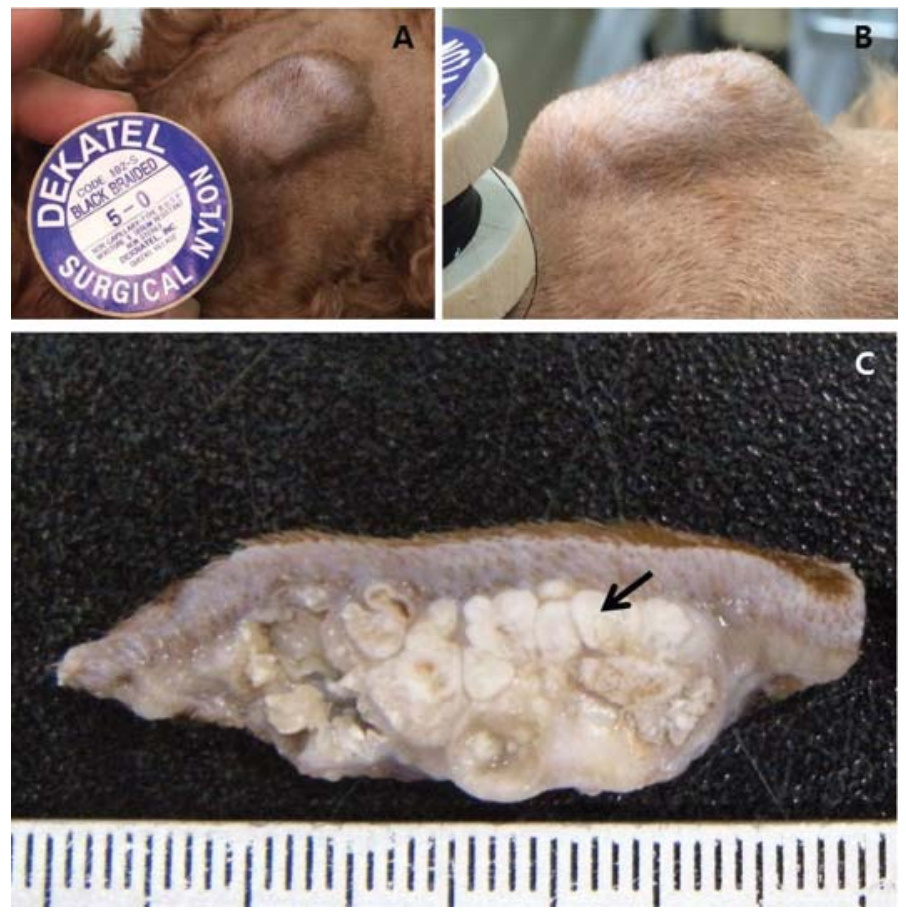

Figure 1. (A) (B) Gross findings. The mass was protruded. The size of the mass was $3 \times$ $2 \times 1.5 \mathrm{~cm}$. (C) The cut surface of the mass. The mass was located in the deep dermis and subcutaneous layer. The mass was lobulated with a thin collagen septum. The mass was filled with white chalky materials (arrow).

The specimen was fixed in a 10\% neutral buffered formalin solution and routinely processed. The sections were cut into 6- $\mu \mathrm{m}$-thick slices and stained with hematoxylin and eosin (H\&E). For immunohistochemical study, $\beta$ - catenin antibody (Santacruz) was used. 

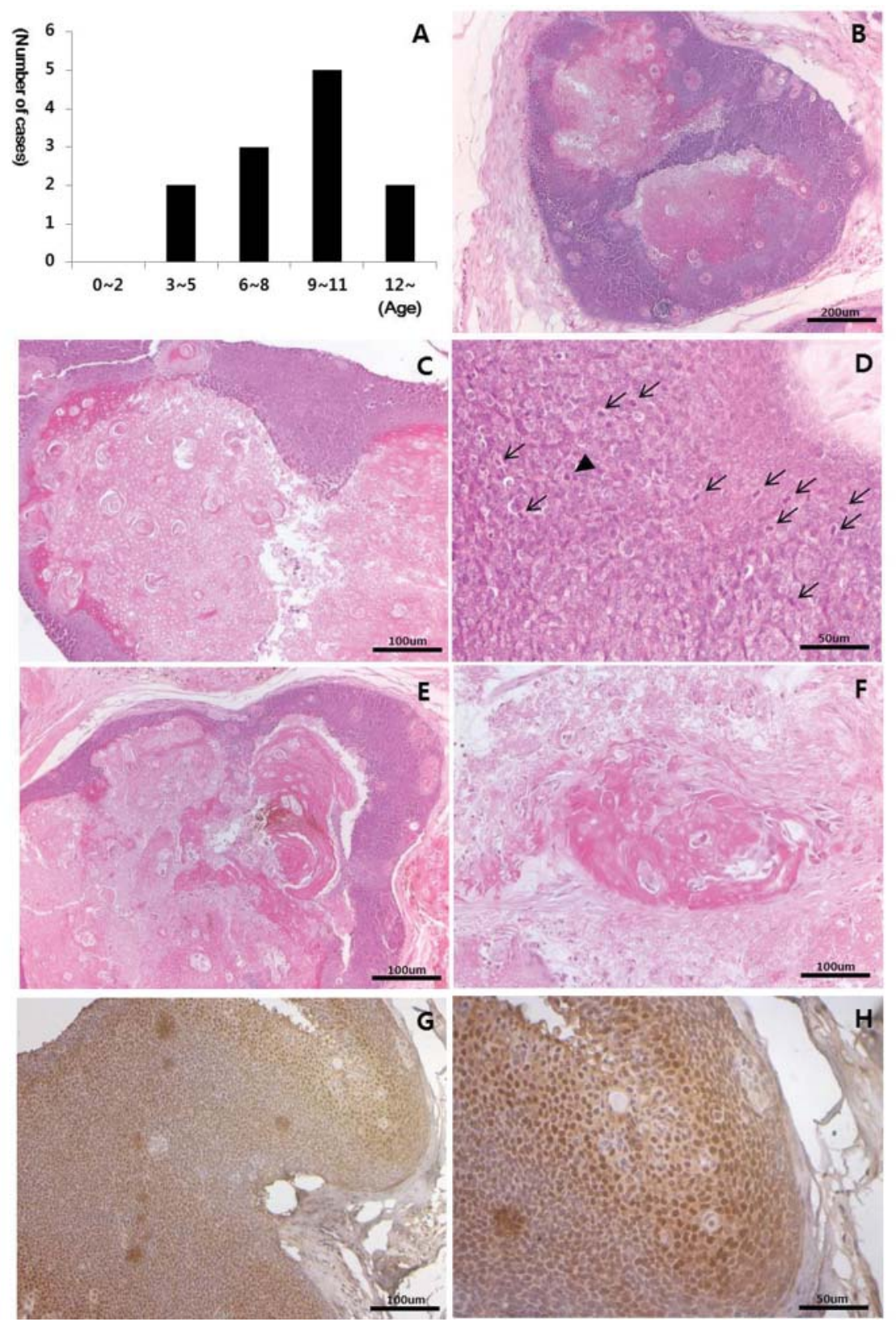

Figure 2. (A) The age of the reported cases of canine malignant pilomatricoma. There is no case of canine malignant pilomatricoma from neonatal to 2 years old. (B) The mass was composed of both basaloid cells and ghost cells. The ratio of the basaloid cells to ghost cells was high. (C) Abrupt keratinization was observed. (D) Mitotic index was high (arrows) and mitotic atypia was distinct (arrowhead). (E) Melanin pigments were observed. (F) Osseous metaplasia was observed. $(\mathbf{G})$ and $(\mathbf{H})$ Immunohistochemistry for $\beta$-catenin. The neoplastic cells were strongly positive for $\beta$ - catenin. 
The microscopy findings revealed that the mass was composed of several lobules. The ratio of the basaloid cells to ghost cells was high (Figure 2B). At the periphery of the lobules there were round to oval basaloid cells with hyperchromatic nuclei and scant cytoplasm (Figure 2C). The basaloid cells differentiated toward the center of the lobules and frequently showed mitotic figures (7-15 mitotic figures per $400 \times$ high power field). Significant nuclear and mitotic atypia were observed (Figure 2D). Melanin pigments were present in the basaloid neoplastic cells (Figure 2E). The cellularity was high. The cells exhibited abrupt kertinization and marked pleomorphism.

The centers of the lobules contained ghost cell clusters (shadow cells) and foci of calcification. The ghost cells had abundant eosinophilic cytoplasm and a round empty space due to the absence of the nucleus. No metastasis was observed. Osseous metaplasia was noticed in the center of the lobules (Figure 2F).

For making more precise diagnosis, we performed immunohistochemical staining against $\beta$-catenin. The nucleus of the neoplastic basaloid cells were strongly positive for $\beta$-catenin (Figures $2 \mathrm{G}$ and $2 \mathrm{H}$ ).

Malignant pilomatricoma is a hair follicle-derived tumor with matrical differentiation. The histological characteristics of MP are similar to those of benign pilomatricoma: multiple lobules, basaloid cells at the periphery of the lobules, ghost cells in the center of the lobules, and matrical differentiation. However, MP differs from the benign form of the pilomatricoma in terms of its increased mitotic figures; rapid growth; a high ratio of basaloid to ghost cells; lymphatic invasion; metastasis to other organs such as the bone, lung, liver and spleen; and recurrence after excision. Although metastasis was not observed in the microscopic findings in the present case, the neoplasm was determined to be a malignant pilomatricoma on the basis of the histological findings of numerous mitotic figures with mitotic atypia, nuclear pleomorphism, and bone metaplasia. Mitotic figures can be found in both the benign and malignant forms of pilomatricoma. However, the frequency and atypia of the mitotic figures are important to differentiate MP from its benign counterpart. Moreover, the mitotic figure is a reliable index for the differentiation of malignant forms from the benign counterparts in most of the tumors. In the present case, the ratio of the basaloid to ghost cells was high, which is one of the critical factors for differentiating MP from benign pilomatricoma. This high ratio demonstrates that the neoplastic basaloid cells of the tumor have a tendency towards active neoplastic proliferation rather than differentiation. In both benign and malignant pilomatricoma, basaloid cells express $\beta$-catenin $[3,4]$. The strong expression of $\beta$-catenin in the nucleus can be a prognostic factor of carcinogenesis [4]. In this case, the neoplastic basaloid cells strongly expressed $\beta$-catenin in the nucleus, while the cytoplasm slightly expressed it, which implies the translocation of $\beta$-catenin to nucleus.

This is the first reported case of malignant pilomatricoma in a 1-year-old young dog. Most neoplasms, except histiocytoma, are more commonly observed in older dogs than in younger ones. There is only 12 reported MP cases so far: three of them were 
from 3-6 years old dogs, two of them were 6-8 years old dogs, five of them were 9-11 years old dogs and others were dogs over 12 years of age All the reported canine MP cases were from middle aged to old dogs. There has been no case of canine MP from neonatal to 2 years old dogs except this present study (Figure 2A). This is the first case of MP in a young dog. Although MP is rarely observed in dogs, the incidence of MP in dogs is on the rise [2,3,5-11]. We suggest that the incidence of MP could increase not only in the older dogs, but also in the younger ones.

\section{Acknowledgements}

This work was funded by Korea Institute of Planning and Evaluation for Technology in Food, Agriculture, Forestry and Fisheries (312062-5).

\section{Authors' contributions}

EJ participated in the design of the study and drafted the manuscript. AY and EM carried out the staining including H\&E and immunohistochemstry. JK helped to draft the manuscript. KS participated in the design of study. All authors read and approved the final manuscript.

\section{Declaration of conflicting interests}

The author(s) declared no potential conflicts of interest with respect to the research, authorship, and/or publication of this article.

\section{REFERENCES}

1. Goldschmidt MH, Hendrick MJ: 2. Tumors of the Skin and Soft Tissues 1 In : Tumors in domestic animals. 4th ed. Blackwell; 2002, 61-63.

2. Da Silva EO, Green KT, Wasques DG, Chaves RO, dos Reis AC, Bracarense AP: Malignant pilomatricoma in a dog. J Comp Pathol 2012, 147:214-217.

3. Martano M, Navas L, Meomartino L, Abramo F, Restucci B, Maiolino P, Muzio LL: Malignant pilomatricoma with multiple bone metastases in a dog: Histological and immunohistochemical study. Exp Ther Med 2013, 5:1005-1008.

4. Bongiovanni L, Malatesta D, Brachelente C,D'Egidio S, Della Salda L. $\beta$-Catenin in Canine Skin: Immunohistochemical Pattern of Expression in Normal Skin and Cutaneous Epithelial Tumours. J Comp Pathol 2011, 145:138-47.

5. Carroll EE, Fossey SL, Mangus LM, Carsillo ME, Rush LJ, McLeod CG, Johnson TO: Malignant pilomatricoma in 3 dogs. Vet Pathol 2010, 47:937-943.

6. Jackson K, Boger L, Goldschmidt M, Walton RM: Malignant pilomatricoma in a softcoated Wheaten Terrier. Vet Clin Pathol 2010, 39:236-240.

7. Ham LV, Bree HV, Maenhout T, Tshamala M, Broekaertt D, Hoorens J, Mattheeuws D: Metastatic pilomatrixoma presenting as paraplegia in a dog. J Small Anim Pract 1991, 32:27-30. 
8. Rodriguez F, Herraez P, Rodriguez E, Gomez-Villamandos JC, Espinosa de los Monteros A: Metastatic pilomatrixoma associated with neurological signs in a dog. Vet Rec 1995, 137:247-248.

9. Goldschmidt MH, Thrall DE, Jeglum KA, Everett JI, Wood MG: Malignant pilomatricoma in a dog. J Cutan Pathol 1981, 8:375-381.

10. Sells DM, Conroy JD: Malignant epithelial neoplasia with hair follicle differentiation in dogs: Malignant pilomatrixoma. J Comp Pathol 1976, 86:121-129.

11. Barrot AC, Carioto L, Gains M, Nadeau ME: Metastatic malignant pilomatrixoma, acanthomatous ameloblastoma, and liver tumor in a dog with polyphagia, polyuria, polydipsia, and weight loss. Can Vet J 2013, 54:387-391.

\section{MALIGNI PILOMATRIKOM KOD MLADOG PSA}

Eun-Joo Lee, Ah-Young Kim, Eun-Mi Lee, Jin-Kyu Park, Kyu-Shik Jeong

Maligni pilomatrikom je maligni tumor folikula samo sa matriksnom diferencijacijom. Radi se o retkom tumoru kod pasa. Malo je podataka koji se odnose na uticaj i predispoziciju pola, rase i starosti na učestalost ovog tumora kod pasa, a postoje radovi koji opisuju maligni pilomatrikom kod pasa srednjeg i starijeg uzrasta. U radu je prikazan slučaj ovog tumora uzorkovan od jednogodišnje minijaturne pudle, muškog pola. Tumorska masa, ustanovljena u dorzalnoj regiji vrata, bila je čvrsta i sa protruzijama, veličine $3 \times 2 \times 1,5 \mathrm{~cm}$. Tumor je bio lokalizovan u dubokom dermisu i potkožju, a tumorska masa sastavljena od nekoliko lobusa, sivo bele strukture nalik na kredu. Histološkim pregledom je uočeno više većih i manjih lobusa, na čijoj periferiji se nalaze bazofilne okrugle do ovalne bazalne ćelije. Bazofilne ćelije su bile keratinizovane. Veći broj ćelija bez jedra i sa velikom količinom eozinofilne citoplazme nalazio se u središnjem delu tumorske mase. Bazofilne bazalne ćelije su posedovale veći broj različitih mitotskih vrednosti. Naglašena je celularnost i pleomorfizam. Nije ustanovljena limfogena metastaza. Ovm je prikazan redak slučaj malignog pilomatrikoma kod mladog jednogodišnjeg psa. 